\title{
LARVAL SURVIVAL OF SPODOPTERA LITURA (F.) FIRST AND SECOND INSTAR ON DUAL TOXIN BT COTTON (CRY 1 AC +2 AB) HYBRIDS AND
}

\section{NON-BT COTTON}

\author{
RAMANJALI. T ${ }^{1}$, SINGH. T. V. $\mathrm{K}^{2}$ \& NARENDRA REDDY. $\mathrm{C}^{3}$ \\ ${ }^{1,3}$ Department .of Entomology, College of Agriculture, PJTSAU, Rejendranagar, Hyderabad, India \\ ${ }^{2}$ Emeritus Scientist - ICAR \& Dean of Agriculture (Rtd.), PJTSAU, Rejendranagar, Hyderabad, India
}

\section{ABSTRACT}

Laboratory assays showed that, dual toxin B. thuringiensis (Bt) cotton cultivars expressing both Cry 1 Ac and Cry 2 Ab endo toxins were more toxic to S. litura, as compared to non-Bt. To observe the survival of first and second in star larvae of S. litura, larvae were reared on leaves, squares and bolls of eleven Bollgard-II cotton hybrids, and non Bt cotton at 60, 75, 90 and 125 DAS of the crop. The mortality of first in star larvae was 100 percent on leaves, where as, it is only 75 per cent on squares of Bollgard-II cotton.

KEYWORDS: Survival, Dual Toxin Bt Cotton \& S. Litura

Received: Aug 14, 2017, Accepted: Sep 05, 2017, Published: Sep 15, 2017, Paper Id: IJZROCT20172

\section{INTRODUCTION}

Cotton is one of the most important cash crops and it is attacked by large number of pests and of these the boll worm complex is considered the major constraint. Plant introduced protein expressing cotton crop has altered the paradigm of crop protection, which used to have Cry 1 Ac gene since 2002. Plant introduced Protein (PIP) delta endo toxin expressing genes (Cry genes) are lepidopteran specific and toxicity symptoms in target larvae include midgut paralysis, altered permeability and disintegration of the midgut epithelium, as well as an altered $\mathrm{pH}$ in the midgut. Insects thus stop feeding, become dehydrated and ultimately die.

Transgenic cotton brought down the usage of insecticides by $60-80 \%$, and increased the population of natural enemies (Hegde et al., 2004). The technology has been anticipated in the management of boll worms, but not for tobacco caterpillar, Spodoptera litura (Fab.), beet armyworm, Spodoptera exigua (Hubner ) and soybean looper, Pseudoplusia includens (Walker ), which are reported to be tolerant to Cry 1 Ac. This prompted scientists, to develop new genetically modified cotton hybrids i.e., dual toxin Bacillus thuringiensis (Bt) cultivar expressing both Cry 1 Ac and Cry 2 Ab endotoxins (Greenplate et al., 2000). The dual toxin PIP cotton technology has used the same source of soil bacterium, with $(\mathrm{Cry} 1 \mathrm{Ac}+2 \mathrm{Ab})$ two genes expressing at the same time, so as to delay the development of resistance to the Bt toxin (Crickmore et al., 1998; Sivasupramaniam et al., 2003). The addition of Cry $2 \mathrm{Ab}$ protein expressed in dual toxin Bt cotton, provides satisfactory control of beet armyworms, fall armyworms and soybean loopers (Stewart et al., 2000). This article reports the results of laboratory assays, with a dual toxin Bt cotton cultivars compared with non Bt. 


\section{MATERIALS AND METHODS}

Bioassays of S. litura larvae were conducted with 11 dual toxin cultivars viz., Ajeeth-155, Ankur-3034, Chetak, ATM, Bhakti, Brahma, Rasi-665, Rasi-668, Denim, Sudarshan, Yuva and non-Bt. Studies were carried out at Bt Lab, Department of Entomology and College Farm, College of Agriculture, Rajendranagar, Hyderabad during kharif-2013. Field plots were maintained by standard agronomic practices, including herbicide and fertilizer applications. This experiment was conducted with first and second instars, and different plant parts namely leaves, squares and bolls of eleven Bg-II and non Bt cotton at different intervals i.e., 60, 75, 90 and 125 DAS.

Feeding on leaves, squares and bolls of dual toxin Bt cotton and single toxin Bt cotton cultivars, was taken up along with non-Bt as control. Tender leaves (top), squares and bolls (at 90 and 125 DAS only) were plucked with $0.5 \mathrm{~cm}$ of petiole remaining, to prevent dessication from the crop of 60, 75,90 and 125 days old dual toxin, and non-Bt cotton were brought to Bt lab. Later, these were cleaned with distilled water and wiped off with blotting paper, to remove excess moisture and air dried. The cleaned leaves, squares and bolls were placed individually into rearing cups. Within 1-2 h of harvesting, a single leaf, 3-4 squares and single boll were placed into individual rearing cups and larvae were placed into each cup. Larval instars cultured on natural diet (i.e. castor leaves) were used with three replications. In each treatment, 15 larvae were kept in rearing cups and the culture was maintained at ambient temperature, in laboratory. Fresh leaves, collected as before, were provided to larvae until death or up to pupation.

Larval survival was recorded on cotton plant parts, at seven days after release (i.e. movement present after disturbance with a camel's hair brush). Larval mortality was worked out as percent, by using Abott's formula.

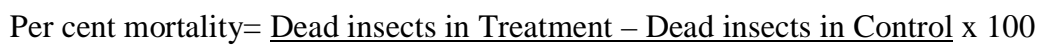

Dead insects in Control

\section{Details of the treatments}

Number of Treatments: Five

Replications: Three

Design: CRD

T1a: 15 first in star larvae fed with leaves of BG-II.

T1b: 15 first in star larvae fed with leaves of non-Bt cotton.

T2a: 15 first in star larvae fed with squares of BG-II.

T2b: 15 first in star larvae fed with squares of non-Bt cotton.

T3a: 15 second in star larvae fed with leaves of BG-II.

T3b: 15 second in star larvae fed with leaves of non-Bt cotton.

T4a: 15 second in star larvae fed with squares of BG-II.

T4b: 15 second in star larvae fed with squares of non-Bt cotton.

T5a: 15 second in star larvae fed with green bolls of BG-II. 
T5b: 15 second in star larvae fed with green bolls of non-Bt cotton.

The above treatments were repeated for all the eleven BG-II cotton hybrids

\section{RESULTS AND DISCUSSIONS}

The percent mortality of first in star larvae on squares of BG-II cotton hybrids (Table.1.), was significantly different from that of non-Bt (6.67-20.00). On squares, the percent mortality of first in star larvae was 41.67, 41.67, 50.00, 58.33, 33.33, 33.33, 58.33, 83.33, 66.67, 50.00, 41.67 at 60 DAS, on Ankur-3034, Ajeeth-155, Chetak, ATM, Bhakti, Brahma, Rasi-665, Rasi-668, Denim, Sudarshan and Yuva, respectively. The percent mortality of first in star larvae on squares of eleven BG-II hybrids, was 70.00, 61.67, 55.00, 61.67, 70.00, 53.33, 70.00, 93.33, 76.67, 61.67, 53.33 at 75 DAS on Ankur-3034, Ajeeth-155, Chetak, ATM, Bhakti, Brahma, Rasi-665, Rasi-668, Denim, Sudarshan and Yuva, respectively. The percent mortality of first in star larvae was 56.67, 41.67, 50.00, 56.67, 50.00, 56.67, 51.67, 78.33, 86.67, 78.33, 50.00, 50.00 at 90 DAS on Ankur-3034, Ajeeth-155, Chetak, ATM, Bhakti, Brahma, Rasi-665, Rasi-668, Denim, Sudarshan and Yuva, respectively. The percent mortality of first in star larvae on squares of eleven BG-II hybrids was $50.00,41.67,50.00,50.00,41.67,50.00,75.00,66.67,58.33,40.00,41.67$ at 125 DAS, on Ankur-3034, Ajeeth-155, Chetak, ATM, Bhakti, Brahma, Rasi-665, Rasi-668, Denim, Sudarshan and Yuva, respectively.

The percent mortality of first in star larvae, fed with squares of eleven BG-II cotton hybrids, ranged in between 33.33-83.33 at 60 DAS, 53.33-93.33 at 75 DAS, 50.00-86.67 at 90 DAS and 40.00-75.00 at 125 DAS, respectively. The highest per cent mortality of first in star larvae was recorded in Rasi-665 at 60, 75, 90 and 125 DAS. The percent mortality in Rasi-665 was significantly different from the other BG-II cotton hybrids at 60, 75 and 125 DAS, while Rasi-665, Rasi668 and Denim were at par, in terms of percent mortality at 90 DAS. The lowest percent mortality was recorded in Brahma (33.33 and 53.33 per cent) at 60 and 75 DAS, Ajeeth-155 (50.00 per cent) at 90 DAS and Sudarshan (40.00 per cent) at 125 DAS.

The percent mortality of second in star larvae on leaves of BG-II cotton hybrids (Table.2.) was 61.67, 53.33, 61.67, 70.00, 55.00, 70.00, 76.67, 76.67, 68.33, 55.00, 70.00, at 60 DAS on Ankur-3034, Ajeeth-155, Chetak, ATM, Bhakti, Brahma, Rasi-665, Rasi-668, Denim, Sudarshan and Yuva, respectively. The percent mortality of second instar larvae was 70.00, 68.33, 68.33, 85.00, 70.00, 61.67, 76.67, 85.00, 68.33, 53.33, 53.33 at 75 DAS on Ankur-3034, Ajeeth155, Chetak, ATM, Bhakti, Brahma, Rasi-665, Rasi-668, Denim, Sudarshan and Yuva, respectively. The percent mortality of second in star larvae was 50.00, 41.67, 58.33, 50.00, 41.67, 41.67, 66.67, 83.33, 75.00, 58.33, 41.67 at 90 DAS on Ankur-3034, Ajeeth-155, Chetak, ATM, Bhakti, Brahma, Rasi-665, Rasi-668, Denim, Sudarshan and Yuva, respectively. The percent mortality of second in star larvae was 46.67, 38.33, 53.33, 38.33, 45.00, 38.33, 53.33, 61.67, 53.33, 30.00, 23.33 at 125 DAS on Ankur-3034, Ajeeth-155, Chetak, ATM, Bhakti, Brahma, Rasi-665, Rasi-668, Denim, Sudarshan and Yuva, respectively.

The percent mortality of second in star larvae of S. litura on leaves of BG-II cotton hybrids, ranged in between 53.33-76.67 at 60 DAS, 53.33-85.00 at 75 DAS, 41.67-83.33 at 90 DAS and 38.33-61.67 at 125 DAS, respectively. The percent mortality of second in star larvae of $S$. litura on leaves of eleven BG-II cotton hybrids were significantly superior over non-Bt (13.33-20.00), at 60, 75, 90 and 125 days, after sowing (DAS) of the crop. The highest percent mortality of second in star larvae was recorded in Rasi-665 at 60, 75, 90 and 125 DAS. The lowest percent larval mortality was recorded in Ajeeth-155 (53.33, 41.67\%) at 60 and 90 DAS, Yuva (53.33, 23.33\%) at 75 and 125 DAS (Table.2). The 
percent mortality in Rasi-665 was on par with Rasi-668, Ankur-3034, Chetak, ATM, Brahma, Denim and Yuva at 60 DAS. The percent mortality in Rasi-665 was on par with Ankur-3034, Ajeeth-155, Chetak, ATM, Bhakti, Brahma, Denim and Rasi- 668 at 75 DAS. The percent mortality in Rasi-665 was significantly differed with the other hybrids, at 90 DAS. The BG-II cotton hybrids Rasi-665, Denim and Rasi-668 were on par, in terms of percent mortality at 125 DAS.

The percent mortality of second instar larvae, on squares of eleven BG-II (Table.1.) cotton hybrids were significantly superior over non-Bt mortality (0.00-6.67 percent). The percent mortality of second instar larvae, on squares of BG-II cotton hybrids was 46.67, 40.00, 66.67, 60.00, 40.00, 53.33, 53.33, 73.33, 66.67, 46.67, 60.00 at 60 DAS on Ankur-3034, Ajeeth-155, Chetak, ATM, Bhakti, Brahma, Rasi-665, Rasi-668, Denim, Sudarshan and Yuva, respectively. The percent mortality of second in star larvae was 56.67, 50.00, 56.67, 63.33, 71.67, 65.00, 65.00, 86.67, 65.00, 43.33, 43.33 at 75 DAS on Ankur-3034, Ajeeth-155, Chetak, ATM, Bhakti, Brahma, Rasi-665, Rasi-668, Denim, Sudarshan and Yuva, respectively. The per cent mortality of second in star larvae was 56.67, 43.33, 56.67, 53.33, 50.00, 43.33, 60.00, 80.00, 80.00, 53.33, 53.33 at 90 DAS on Ankur-3034, Ajeeth-155, Chetak, ATM, Bhakti, Brahma, Rasi-665, Rasi-668, Denim, Sudarshan and Yuva, respectively. The percent mortality of second in star larvae was 40.00, 43.33, 50.00, 50.00, 43.33, 40.00, 56.67, 78.33, 56.67, 50.00 and 43.33 at 125 DAS on Ankur-3034, Ajeeth-155, Chetak, ATM, Bhakti, Brahma, Rasi-665, Rasi-668, Denim, Sudarshan and Yuva, respectively.

In case of second instar larvae, the percent mortality ranged in between 40.00-73.33, 43.33-86.67, 43.33-80.00 and 40.00-78.33 at 60, 75, 90 and 125 DAS, respectively. Rasi-665 recorded highest second instar larval mortality at 60, 75, 90 and 125 DAS. The percent mortality in Rasi-665 was on par with Chetak and Rasi-668 at 60 DAS, while, the Rasi665 significantly differed with the other BG-II cotton hybrids at 75, 90 and 125 DAS. The percent of larval mortality was lowest in Ajeeth-155 (40.00 and 43.00 percent) at 60 and 90 DAS, Yuva (43.33 percent) at 75 DAS and Brahma (40.00 percent) at 125 DAS.

The percent mortality of second in star larvae was 66.67, 33.33, 53.33, 53.33, 33.33, 46.67, 66.67, 66.67, 46.67, 40.00, 46.67 at 90 DAS on Ankur-3034, Ajeeth-155, Chetak, ATM, Bhakti, Brahma, Rasi-665, Rasi-668, Denim, Sudarshan and Yuva, respectively. The percent mortality of second in star larvae was 43.33, 28.33, 30.00, 46.67, 21.67, 28.33, 50.00, 35.00, 30.00, 21.67, 30.00 at 125 DAS on Ankur-3034, Ajeeth-155, Chetak, ATM, Bhakti, Brahma, Rasi665, Rasi-668, Denim, Sudarshan and Yuva, respectively.

The percent mortality of second in star larvae on bolls of eleven BG-II cotton hybrids (Table.3.) was superior over non-Bt mortality (0.00-6.67\%) at 90 and 125 DAS. In case of second in star larvae, the percent mortality ranged in between 33.33-66.67 at 90 DAS and 21.67-46.67 at 125 DAS, respectively. The highest second in star larval mortality was recorded on Denim, Ankur-3034 and Rasi-665 at 90 DAS and Denim at 125 DAS. The percent mortality of Denim, Ankur-3034 and Rasi-665 was not on par with other hybrids at 90 DAS, while, Ankur-3034, ATM and Denim were on par at 125 DAS. Ajeeth-155 and Bhakti at 90 DAS and Sudarshan and Bhakti at 125 DAS recorded lowest larval mortality.

Generally, the mortality of the larvae fed with dual toxin Bt and non-Bt cultivars, indicated significantly high mortality, when fed with dual toxin Bt cultivars compared to those fed with non Bt hybrids, and among the Bt-II and nonBt. The mortality of first in star larvae was more on BG-II cotton compared to second in star. Within the plant parts, the mortality was more in case of leaves compared to squares and bolls. The present findings derive support from Dong Lin et al. (2006), who studied the effect of S. litura on dual toxin Bt cotton, non-Bt cotton and found higher mortality on dual toxin Bt cotton, over non-Bt cultivars. Henneberry et al. (2001), studied the effects of transgenic cotton on cabbage looper, 
Larval Survival of Spodoptera Litura $(F$.$) First and Second in star on$

tobacco budworm, beet armyworm and the mortality was 95\%, 100\% and 57\%, respectively. Henneberry et al. (2001) reported cent percent mortality of neonate larvae of beet armyworm, on leaves compared to $96 \%$ mortality on squares of the Bt hybrids.

\section{ACKNOWLEDGEMENT}

The authors are highly thankful to Monsanto company, Bengaluru, India.

\section{CONCLUSIONS}

The mortality decreased with the increase in the age of the crop, as there was decrease in Cry protein expression with advancement in the age of the crop. Kranthi et al. (2005), studied the correlation between mortality and Cry protein expression, which indicated that, higher the Cry content, more number of larvae died, but as the crop advanced the Cry protein expression reduced

\section{REFERENCES}

1. Crickmore, N. Zeigler, D.R. Feitelson, J. Schnepf, E. Van Rie, J. Lereclus, D. Baum, J. Dean, D.H. (1998) Revision of the nomenclature for the Bacillus thuringiensis pesticidal crystal proteins. Micro. and Mol. Bio. Rev. 62(3):807-813.

2. Dong, Lin. Nai-Yong Liu. Peng He. (2006). Binding properties of pheromone-binding protein 1 from the common cutworm Spodoptera litura. Education Ministry Key Laboratory of Integrated Management of Crop Diseases and Pests, College of Plant Protection, Nanjing Agricultural University, Nanjing 210095, China. 161(4):295-302.

3. Greenplate, J.T. Penn, S.R. Shappley, Z. Oppenhuizen, M.J. Reich, M.B. and Osborn. J. (2000). Bollgard II efficacy: quantification of lepidopteran activity in a 2-gene product. In P. Dugger and D. Richter [eds.], Proceedings. Beltwide Cotton Conference Nat. Cott. Coun, Memphis, TN. 1041-1043.

4. Raghuvir Singh, Sam A Masih et al., Bt Cotton Plant Cultivation at Low Temperature does Not Affect Horizontal Gene Transfer to Soil Bacteria but Decreases Seed Cotton Yield, International Journal of Agricultural Science and Research (IJASR), Volume 5, Issue 3, May - Jun 2015, pp. 7-16

5. Hegde, M. Nidagundi, J.M. Biradar, D.P. Udikeri, S.S. and Khadi,B.M. (2004). Performance of Bt and non-Bt cotton hybrids against Insect pests under irrigated condition. In: Int. Symp. on "Strat. for Sust. Cotton Prod., -A Global Vision"- A Global Vision”. 3. Crop Protection, 23-25 November 2004, UAS, Dharwad, Karnataka (INDIA), pp.143-145.

6. Henneberry, T.J. Jech, J.F. and Torre, T. (2001). Effects of transgenic cotton on cabbage looper, tobacco budworm and beet armyworm larval mortality and development and foliage consumption in the laboratory. Southwest. Ento. 26:325-338.

7. Kranthi, K.R. Naidu, S. Dhawad, C.S. Tatwawadi, A. Mate, K. Patil, E. Bharose, A.A. Behera, G.T. Wasaskar, R.M and Kranthi, S. (2005). Temporal and intra-plant variability of Cry 1 Ac expressing in Bt-cotton and its influence on the survival of cotton bollworm, Helicoverpa armigera (Hubner) (Noctuidae: Lepidoptera).Cur.Sci. 89: 291-298.

8. Sivasupramaniam, S. Moar, W.J. Ruschke, L.G. Osborn, J.A. Jiang, C. Sebaugh, J.L. Brown, G.R. Shappley, Z.W. Oppenhuizen, M.E. Mullins, J.W. and Greenplate, J.T. (2008). Toxicity and characterization of cotton expressing Bacillus thuringiensis Cry 1 Ac and Cry 2 Ab 2 proteins for control of lepidopteran pests. J. Eco. Ento. 101: 546-554.

9. Stewart, S.D. and Knighten, K.S. 2000. Efficacy of Bt cotton expressing two insecticidal proteins Bacillus thuringiensis Berliner on selected caterpillar pests. Beltwide Cotton Conference. Sant Antanio, USA. Pp415-417. 


\section{APPENDICES}

Table 1: Per Cent Mortality of First and Second Larval in Stars of $S$. Litura on Squares of Test Hybrids

\begin{tabular}{|c|c|c|c|c|c|c|c|c|}
\hline \multirow{2}{*}{ Treatments } & \multicolumn{4}{|c|}{ Mortality of I In Star larvae (per cent) } & \multicolumn{4}{|c|}{ Mortality of II In star larvae (per cent) } \\
\hline & 60 DAS & 75 DAS & 90 DAS & 125 DAS & 60 DAS & 75 DAS & 90 DAS & 125 DAS \\
\hline Ankur-3034 & $\begin{array}{c}41.67 \\
(39.98)^{\mathrm{cd}}\end{array}$ & $\begin{array}{c}70.00 \\
(56.90)^{\mathrm{bc}}\end{array}$ & $\begin{array}{c}56.67 \\
(48.82)^{\mathrm{b}}\end{array}$ & $\begin{array}{c}50.00 \\
(44.98)^{\mathrm{cd}}\end{array}$ & $\begin{array}{c}46.67 \\
(43.06)^{\mathrm{de}}\end{array}$ & $\begin{array}{c}56.67 \\
(48.82)^{\mathrm{bcd}}\end{array}$ & $\begin{array}{c}56.67 \\
(48.82)^{\mathrm{bc}}\end{array}$ & $\begin{array}{c}40.00 \\
(41.13)^{\mathrm{c}}\end{array}$ \\
\hline Ajeet-155 & $\begin{array}{c}41.67 \\
(39.98)^{\mathrm{cd}}\end{array}$ & $\begin{array}{c}61.67 \\
(51.90)^{\mathrm{bc}}\end{array}$ & $\begin{array}{c}50.00 \\
(44.98)^{\mathrm{b}}\end{array}$ & $\begin{array}{c}41.67 \\
(39.98)^{\mathrm{d}}\end{array}$ & $\begin{array}{c}40.00 \\
(39.21)^{\mathrm{e}}\end{array}$ & $\begin{array}{c}50.00 \\
(44.98)^{\mathrm{cd}}\end{array}$ & $\begin{array}{c}43.33 \\
(41.13)^{\mathrm{d}}\end{array}$ & $\begin{array}{c}43.33 \\
(49.98)^{\mathrm{bc}}\end{array}$ \\
\hline Chetak & $\begin{array}{c}50.00 \\
(44.98)^{\mathrm{bcd}}\end{array}$ & $\begin{array}{c}55.00 \\
(48.05)^{\mathrm{c}}\end{array}$ & $\begin{array}{c}56.67 \\
(48.82)^{\mathrm{b}}\end{array}$ & $\begin{array}{c}50.00 \\
(44.98)^{\mathrm{cd}}\end{array}$ & $\begin{array}{c}66.67 \\
(54.96)^{\mathrm{ab}}\end{array}$ & $\begin{array}{c}56.67 \\
(48.82)^{\mathrm{bcd}}\end{array}$ & $\begin{array}{c}56.67 \\
(48.82)^{\mathrm{bc}}\end{array}$ & $\begin{array}{c}50.00 \\
(48.82)^{\mathrm{bc}}\end{array}$ \\
\hline ATM & $\begin{array}{c}58.33 \\
(49.98)^{\mathrm{bc}}\end{array}$ & $\begin{array}{c}61.67 \\
(51.90)^{\mathrm{bc}}\end{array}$ & $\begin{array}{c}50.00 \\
(44.98)^{\mathrm{b}}\end{array}$ & $\begin{array}{c}50.00 \\
(44.98)^{\mathrm{cd}}\end{array}$ & $\begin{array}{c}60.00 \\
(50.74)^{\mathrm{bc}}\end{array}$ & $\begin{array}{c}63.33 \\
(53.04)^{\mathrm{bc}}\end{array}$ & $\begin{array}{c}53.33 \\
(46.90)^{\mathrm{bc}}\end{array}$ & $\begin{array}{c}50.00 \\
(44.98)^{\mathrm{bc}}\end{array}$ \\
\hline Bhakti & $\begin{array}{c}33.33 \\
(34.98)^{\mathrm{de}}\end{array}$ & $\begin{array}{c}70.00 \\
(56.90)^{\mathrm{bc}}\end{array}$ & $\begin{array}{c}56.67 \\
(48.82)^{\mathrm{b}}\end{array}$ & $\begin{array}{c}41.67 \\
(39.98)^{\mathrm{d}}\end{array}$ & $\begin{array}{c}40.00 \\
(39.21)^{\mathrm{e}}\end{array}$ & $\begin{array}{c}71.67 \\
(58.04)^{\mathrm{b}}\end{array}$ & $\begin{array}{c}50.00 \\
(44.98)^{\mathrm{cd}}\end{array}$ & $\begin{array}{c}43.33 \\
(41.13)^{\mathrm{bc}}\end{array}$ \\
\hline Brahma & $\begin{array}{c}33.33 \\
(34.98)^{\mathrm{de}}\end{array}$ & $\begin{array}{c}53.33 \\
(46.90)^{\mathrm{c}}\end{array}$ & $\begin{array}{c}51.67 \\
(46.13)^{\mathrm{b}}\end{array}$ & $\begin{array}{c}50.00 \\
(44.98)^{\mathrm{cd}}\end{array}$ & $\begin{array}{c}53.33 \\
(46.90)^{\mathrm{cd}}\end{array}$ & $\begin{array}{c}65.00 \\
(53.82)^{\mathrm{bc}}\end{array}$ & $\begin{array}{c}43.33 \\
(41.13)^{\mathrm{d}}\end{array}$ & $\begin{array}{c}40.00 \\
(39.21)^{\mathrm{c}}\end{array}$ \\
\hline Denim & $\begin{array}{c}58.33 \\
(49.98)^{\mathrm{bc}}\end{array}$ & $\begin{array}{c}70.00 \\
(56.90)^{\mathrm{bc}}\end{array}$ & $\begin{array}{c}78.33 \\
(62.26)^{\mathrm{a}}\end{array}$ & $\begin{array}{c}75.00 \\
(59.97)^{\mathrm{a}}\end{array}$ & $\begin{array}{c}53.33 \\
(46.90)^{\mathrm{cd}}\end{array}$ & $\begin{array}{c}65.00 \\
(53.82)^{\mathrm{bc}}\end{array}$ & $\begin{array}{c}60.00 \\
(50.74)^{\mathrm{b}}\end{array}$ & $\begin{array}{c}56.67 \\
(49.20)^{\mathrm{b}}\end{array}$ \\
\hline Rasi-665 & $\begin{array}{c}83.33 \\
(74.99)^{\mathrm{a}} \\
\end{array}$ & $\begin{array}{c}93.33 \\
(79.99)^{\mathrm{a}} \\
\end{array}$ & $\begin{array}{c}86.67 \\
(72.27)^{\mathrm{a}} \\
\end{array}$ & $\begin{array}{c}66.67 \\
(54.97)^{\mathrm{ab}} \\
\end{array}$ & $\begin{array}{c}73.33 \\
(59.18)^{\mathrm{a}} \\
\end{array}$ & $\begin{array}{c}86.67 \\
(72.27)^{\mathrm{a}} \\
\end{array}$ & $\begin{array}{c}80.00 \\
(63.40)^{\mathrm{a}} \\
\end{array}$ & $\begin{array}{c}78.33 \\
(62.26)^{\mathrm{a}} \\
\end{array}$ \\
\hline Rasi-668 & $\begin{array}{c}66.67 \\
(54.97)^{\mathrm{ab}}\end{array}$ & $\begin{array}{c}76.67 \\
(61.12)^{b}\end{array}$ & $\begin{array}{c}78.33 \\
(62.26)^{\mathrm{a}}\end{array}$ & $\begin{array}{c}58.33 \\
(49.98)^{\mathrm{bc}}\end{array}$ & $\begin{array}{c}66.67 \\
(54.96)^{\mathrm{ab}}\end{array}$ & $\begin{array}{c}65.00 \\
(53.82)^{\mathrm{bc}}\end{array}$ & $\begin{array}{c}60.00 \\
(50.74)^{\mathrm{b}}\end{array}$ & $\begin{array}{c}56.67 \\
(49.20)^{\mathrm{b}}\end{array}$ \\
\hline Sudarshan & $\begin{array}{c}50.00 \\
(44.98)^{\mathrm{bcd}}\end{array}$ & $\begin{array}{c}61.67 \\
(51.90)^{\mathrm{bc}}\end{array}$ & $\begin{array}{c}50.00 \\
(44.98)^{\mathrm{b}}\end{array}$ & $\begin{array}{c}40.00 \\
(38.83)^{\mathrm{d}}\end{array}$ & $\begin{array}{c}46.67 \\
(43.06)^{\mathrm{de}}\end{array}$ & $\begin{array}{c}43.33 \\
(41.13)^{\mathrm{d}}\end{array}$ & $\begin{array}{c}53.33 \\
(46.90)^{\mathrm{bc}}\end{array}$ & $\begin{array}{c}50.00 \\
(44.98)^{\mathrm{bc}}\end{array}$ \\
\hline Yuva & $\begin{array}{c}41.67 \\
(39.98)^{\mathrm{cd}}\end{array}$ & $\begin{array}{c}53.33 \\
(46.90)^{\mathrm{c}}\end{array}$ & $\begin{array}{c}50.00 \\
(44.98)^{\mathrm{b}}\end{array}$ & $\begin{array}{c}41.67 \\
(39.98)^{d}\end{array}$ & $\begin{array}{c}60.00 \\
(50.74)^{\mathrm{bc}}\end{array}$ & $\begin{array}{c}43.33 \\
(41.13)^{\mathrm{d}}\end{array}$ & $\begin{array}{c}53.33 \\
(46.90)^{\mathrm{bc}}\end{array}$ & $\begin{array}{c}43.33 \\
(41.13)^{\mathrm{bc}}\end{array}$ \\
\hline Control & $\begin{array}{c}20.00 \\
(26.55)^{\mathrm{e}}\end{array}$ & $\begin{array}{c}13.33 \\
(17.70)^{\mathrm{d}}\end{array}$ & $\begin{array}{c}6.67 \\
(8.85)^{\mathrm{c}}\end{array}$ & $\begin{array}{c}20.00 \\
(26.55)^{\mathrm{e}}\end{array}$ & $\begin{array}{c}0.00 \\
(0.00)^{\mathrm{f}}\end{array}$ & $\begin{array}{c}6.67 \\
(8.85)^{\mathrm{e}}\end{array}$ & $\begin{array}{c}0.00 \\
(0.00)^{\mathrm{e}}\end{array}$ & $\begin{array}{c}6.67 \\
(8.85)^{\mathrm{d}}\end{array}$ \\
\hline CD & 17.47 & 14.70 & 10.80 & 14.37 & 8.99 & 13.53 & 6,51 & 12.86 \\
\hline SE(m) & 5.95 & 5.00 & 3.68 & 4.89 & 3.06 & 4.61 & 2.21 & 4.38 \\
\hline
\end{tabular}

Figures in parentheses are angular transformed values; Numbers followed by same superscript are not statistically different.

Table 2: Per Cent Mortality of $S$. Litura Larvae on Leaves of Test Hybrids

\begin{tabular}{|l|c|c|c|c|}
\hline \multirow{2}{*}{ Treatments } & \multicolumn{4}{|c|}{ Mortality of II In star Larvae (per cent) } \\
\cline { 2 - 5 } & 60 DAS $^{*}$ Ankur-3034 & 75 DAS & 90 DAS & 125 DAS \\
& $(51.67$ & 70.00 & 50.00 & 46.67 \\
& $(51.90)^{\mathrm{abc}}$ & $(56.90)^{\mathrm{abc}}$ & $(44.98)^{\mathrm{de}}$ & $(43.06)^{\mathrm{bc}}$ \\
\hline \multirow{2}{*}{ Ajeet-155 } & 53.33 & 68.33 & 41.67 & 38.33 \\
& $(46.90)^{\mathrm{c}}$ & $(56.12)^{\mathrm{abc}}$ & $(39.98)^{\mathrm{e}}$ & $(38.06)^{\mathrm{cd}}$ \\
\hline \multirow{2}{*}{ Chetak } & 61.67 & 68.33 & 58.33 & 53.33 \\
& $(51.90)^{\mathrm{abc}}$ & $(56.12)^{\mathrm{abc}}$ & $(49.98)^{\mathrm{cd}}$ & $(46.90)^{\mathrm{ab}}$ \\
\hline \multirow{2}{*}{ ATM } & 70.00 & 85.00 & 50.00 & 38.33 \\
& $(56.90)^{\mathrm{ab}}$ & $(71.12)^{\mathrm{a}}$ & $(44.98)^{\mathrm{de}}$ & $(38.06)^{\mathrm{cd}}$ \\
\hline \multirow{2}{*}{ Bhakti } & 55.00 & 70.00 & 41.67 & 45.00 \\
& $(48.05)^{\mathrm{bc}}$ & $(56.90)^{\mathrm{abc}}$ & $(39.98)^{\mathrm{e}}$ & $(41.90)^{\mathrm{bc}}$ \\
\hline \multirow{2}{*}{ Brahma } & 70.00 & 61.67 & 41.67 & 38.33 \\
& $(56.90)^{\mathrm{ab}}$ & $(51.90)^{\mathrm{bc}}$ & $(39.98)^{\mathrm{e}}$ & $(38.06)^{\mathrm{cd}}$ \\
\hline \multirow{2}{*}{ Denim } & 76.67 & 76.67 & 66.67 & 53.33 \\
& $(61.12)^{\mathrm{a}}$ & $(61.12)^{\mathrm{ab}}$ & $(54.97)^{\mathrm{bc}}$ & $(46.90)^{\mathrm{ab}}$ \\
\hline \multirow{2}{*}{ Rasi-665 } & 76.67 & 85.00 & 83.33 & 61.67 \\
& $(61.12)^{\mathrm{a}}$ & $(71.12)^{\mathrm{a}}$ & $(69.98)^{\mathrm{a}}$ & $(51.90)^{\mathrm{a}}$ \\
\hline \multirow{2}{*}{ Rasi-668 } & 68.33 & 68.33 & 75.00 & 53.33 \\
& $(56.12)^{\mathrm{abc}}$ & $(56.12)^{\mathrm{abc}}$ & $(59.97)^{\mathrm{ab}}$ & $(46.90)^{\mathrm{ab}}$ \\
\hline Sudarshan & $55.00(48.05)^{\mathrm{bc}}$ & $53.33(46.90)^{\mathrm{c}}$ & $58.33(49.98)^{\mathrm{cd}}$ & $30.00(33.06)^{\mathrm{de}}$ \\
\hline
\end{tabular}



Dual Toxin Bt Cotton (Cry 1 AC +2 AB) Hybrids and Non-Bt Cotton

\begin{tabular}{|l|c|c|c|c|}
\hline \multicolumn{5}{|c|}{ Table 2: Contd., } \\
\hline \multirow{2}{*}{ Yuva } & $\begin{array}{c}70.00 \\
(56.90)^{\mathrm{ab}}\end{array}$ & $\begin{array}{c}53.33 \\
(46.90)^{\mathrm{c}}\end{array}$ & $\begin{array}{c}41.67 \\
(39.98)^{\mathrm{e}}\end{array}$ & $\begin{array}{c}23.33 \\
(28.84)^{\text {ef }}\end{array}$ \\
\hline \multirow{2}{*}{ Control } & 13.33 & 13.33 & 20.00 & 13.33 \\
& $(17.70)^{\mathrm{d}}$ & $(17.70)^{\mathrm{d}}$ & $(26.55)^{\mathrm{f}}$ & $(17.70)^{\mathrm{f}}$ \\
\hline CD & 13.66 & 16.97 & 14.05 & 12.52 \\
\hline SE(m) & 4.653 & 5.781 & 4.78 & 4.26 \\
\hline
\end{tabular}

Figures in parentheses are angular transformed values; Numbers followed by same superscript are not statistically different. *First in star mortality was cent per cent on BG-II leaves

Table.3: Per Cent Mortality of $S$. Litura Larvae on Bolls of Test Hybrids

\begin{tabular}{|c|c|c|}
\hline \multirow{2}{*}{ Treatments } & \multicolumn{2}{|c|}{ Mortality of II In star Larvae (Per Cent) } \\
\hline & 90 DAS & 125 DAS \\
\hline Ankur-3034 & $\begin{array}{c}66.67 \\
(54.97)^{\mathrm{a}}\end{array}$ & $\begin{array}{c}43.33 \\
(40.76)^{\mathrm{abc}}\end{array}$ \\
\hline Ajeet-155 & $\begin{array}{c}33.33 \\
(34.99)^{\mathrm{d}}\end{array}$ & $\begin{array}{c}28.33 \\
(31.91)^{\mathrm{de}}\end{array}$ \\
\hline Chetak & $\begin{array}{c}53.33 \\
(46.90)^{\mathrm{b}}\end{array}$ & $\begin{array}{c}30.00 \\
(33.06)^{\text {cde }}\end{array}$ \\
\hline ATM & $\begin{array}{c}53.33 \\
(46.90)^{\mathrm{b}}\end{array}$ & $\begin{array}{c}46.67 \\
(43.06)^{\mathrm{ab}}\end{array}$ \\
\hline Bhakti & $\begin{array}{c}33.33 \\
(34.99)^{\mathrm{d}}\end{array}$ & $\begin{array}{c}21.67 \\
(27.69)^{\mathrm{e}}\end{array}$ \\
\hline Brahma & $\begin{array}{c}46.67 \\
(43.06)^{\mathrm{bc}}\end{array}$ & $\begin{array}{c}28.33 \\
(31.91)^{\mathrm{de}}\end{array}$ \\
\hline Denim & $\begin{array}{c}66.67 \\
(54.96)^{\mathrm{a}}\end{array}$ & $\begin{array}{c}50.00 \\
(44.98)^{\mathrm{a}}\end{array}$ \\
\hline Rasi-665 & $\begin{array}{c}66.67 \\
(54.96)^{\mathrm{a}}\end{array}$ & $\begin{array}{c}35.00 \\
(36.14)^{\text {bcde }}\end{array}$ \\
\hline Rasi-668 & $\begin{array}{c}46.67 \\
(43.06)^{d}\end{array}$ & $\begin{array}{c}30.00 \\
(33.06)^{\mathrm{cde}}\end{array}$ \\
\hline Sudarshan & $\begin{array}{c}40.00 \\
(39.21)^{\mathrm{cd}}\end{array}$ & $\begin{array}{c}21.67 \\
(27.69)^{\mathrm{e}}\end{array}$ \\
\hline Yuva & $\begin{array}{c}46.67 \\
(43.06)^{\mathrm{bc}}\end{array}$ & $\begin{array}{c}30.00 \\
(33.06)^{\mathrm{bcd}}\end{array}$ \\
\hline Control & $\begin{array}{c}0.00 \\
(0.00)^{\mathrm{e}}\end{array}$ & $\begin{array}{c}6.67 \\
(8.85)^{\mathrm{f}}\end{array}$ \\
\hline CD & 10.82 & 12.44 \\
\hline SE(m) & 3.68 & 4.23 \\
\hline
\end{tabular}

Figures in parentheses are angular transformed values; Numbers followed by same superscript are not statistically different 
